\title{
DONOS E PINTORES: PLANTAS E FIGURAÇÃO NA AMAZÔNIA PERUANA
}

\author{
Luisa Elvira Belaunde
}

Este artigo aborda um fenômeno artístico relativamente recente que, se não surgiu de forma isolada no Peru, tem neste país uma presença marcante. Trata-se de um movimento inovador da pintura liderado por artistas indígenas, nascidos e escolarizados na Amazônia, que migraram para Lima, a capital, situada na costa pacífica do país (Landolt 2005; Belaunde 2013a; Bendayán \& Villar 2013a; Cortés Garzón 2015:96-193). O estudo centra-se em dois pintores eminentes deste cenário, Roldán Pinedo e Enrique Casanto, ${ }^{1}$ analisando as conexões entre suas obras e os entornos sociocosmológicos nos quais se inserem. O texto ressalta também o alcance político de suas propostas plásticas e argumenta que os artistas amazônicos introduzem novos modos de olhar na cidade através de suas relações com as plantas e o uso criativo da figuração.

Minha familiaridade com o tema de pesquisa data de 2005, momento em que conheci alguns pintores indígenas residentes em Lima. Desde então acompanho suas trajetórias, prestando-lhes ocasionalmente assistência para a organização de eventos (Belaunde 2010, 2008). Deve-se notar que, apesar do interesse existente tanto no Peru quanto no exterior por suas obras, os pintores não recebem apoio institucional ou financeiro, como aconteceu, por exemplo, na Austrália, no caso dos pintores aborígenes (Myers 1995; Goldstein 2012). Ao chegarem a Lima, os artistas amazônicos precisam tecer parcerias de trabalho para forjarem um nicho e sustentarem-se economicamente, pois a organização das exposições e as vendas de suas telas dependem da intermediação de pessoas aliadas e com influência nos circuitos culturais e comerciais da arte.

Os materiais analisados aqui vêm da minha convivência com os artistas e de entrevistas realizadas em 2015. Nossa interação foi em espanhol, portanto, pretendo apresentar os conceitos que eles mobilizam quando falam nesta língua, ocasionalmente fazendo referência às expressões em língua nativa. Embora imponha restrições, minha abordagem justifica-se pelo fato de ser o espanhol a língua com a qual eles costumam interagir no que diz respeito à sua arte. A palavra pintura, que eles usam para fazer referência às suas obras, não tem tradução equivalente em língua indígena. Normalmente, ambos os pintores usam a palavra em espanhol até quando falam em sua língua nativa. 


\section{Surgimento da nova pintura entre os povos amazônicos peruanos}

Os dois pintores com quem dialogo neste artigo, Enrique Casanto, ashaninka nascido em 1956 e criado na comunidade de Shuringaveni, na região da Selva Central, e Roldán Pinedo, shipibo-konibo nascido em 1971 e criado na comunidade de São Francisco, na região do Ucayali, foram escolarizados na aldeia e não cursaram estudos superiores, nem frequentaram escolas de arte. A originalidade de seus trabalhos reside no fato de terem desenvolvido técnicas pictóricas que juntam elementos dos grafismos ameríndios e da pintura figurativa de proveniência europeia. Esse trânsito entre modos de conceber e materializar as imagens insere-se em movimentos mais amplos na Amazônia peruana atual: passagens entre modos de ser, de conhecer e de fazer, que perpassam as biografias dos artistas e os diferenciam das gerações de seus pais e avós.

Essas mudanças surgiram em face das intervenções do Estado peruano e de outros agentes políticos que, em várias frentes, envolveram os povos amazônicos na turbulenta contemporaneidade nacional peruana. A partir da década de 70, a peruanização dos povos indígenas da Amazônia intensificou-se através de uma série de ações de integração, dentre as quais se destacam: a divisão pelo Estado das terras indígenas em Comunidades Nativas tituladas e a subsequente sedentarização da população em torno das escolas das comunidades; a implementação da escolaridade privilegiando o ensino do espanhol em detrimento da língua e dos conhecimentos nativos; o envolvimento dos jovens indígenas no serviço militar e na guerrilha do Sendero Luminoso e do MRTA (Movimiento Revolucionario Túpac Amaru); e a captura das famílias indígenas nas redes cada vez mais estreitas da economia extrativista da região, incluindo atividades ilegais como o desmatamento, o garimpo e a produção de cocaína para o mercado internacional.

A ação das igrejas católicas e protestantes e das organizações de desenvolvimento social, bem como das federações indígenas nacionais, locais e regionais, também contribuiu, por um lado, para a peruanização das comunidades na floresta e, por outro, incentivou a crescente migração indígena para as cidades. Por sua vez, a conjunção de todos esses processos resultou numa tendência crescente, especialmente entre os jovens, de distanciar-se das gerações anteriores e falar em espanhol. Atualmente, nas cidades, muitos jovens escolarizados de ambos os gêneros preferem autodenominar-se mestizos, pois o espanhol e o estilo de vida dos mestiços estão associados a uma peruanidade mais completa, enquanto a denominação indígena e o uso das línguas nativas estão carregados de conotações de inferioridade e exclusão (Chirif 2015; Trapnell 2015). 
A nova pintura figurativa foi gestada na Amazônia nos últimos 40 anos em meio a essas mudanças sociopolíticas mais abrangentes. Contra a tendência de se adotar uma identidade mestiça homogeneizante, os novos pintores afirmaram a riqueza e a diversidade de suas ancestralidades ameríndias, mas não pretenderam mantê-las intactas e sim gerar uma nova relação com as cidades através das artes visuais. A nova pintura funda-se na apropriação, por parte dos jovens escolarizados, dos procedimentos de enquadramento, composição, desenho, cor e perspectiva apresentados nas ilustrações dos livros da escola e da Igreja, e nos cartazes de propaganda dos estabelecimentos comerciais habitualmente administrados pela população mestiça. Essas técnicas figurativas de fora foram moduladas pelo olhar indígena e combinadas às técnicas gráficas ameríndias aprendidas com os parentes, no dia a dia e nos rituais do ciclo de vida e do xamanismo.

Os estudos etnográficos dos grafismos shipibo-konibo e ashaninka, em particular, destacam a importância dos desenhos feitos com tintas naturais para os processos de produção dos corpos femininos e masculinos, infundindo agência, saúde, poder de sedução e ferocidade nas pessoas e nos artefatos (Roe 1979; Gebhart-Sayer 1985; Illius 1992, 1994; Belaunde 2009; Beysen 2013). As lógicas gráficas ameríndias dos dois povos diferem em vários aspectos, mas compartilham o fato de não procederem de reprodução icônica direta dos seres existentes ao seu redor. Os desenhos consistem em padrões feitos sobre o volume dos corpos e dos artefatos, das roupas e dos enfeites. Eles se aderem aos corpos e objetos, se movimentam com eles e se desmancham com o passar do tempo. Portanto, não são feitos para permanecerem fixos nem para serem admirados separadamente dos outros aspectos corporais aos quais estão ligados (Beysen 2008:91; Belaunde 2013b:201).

Com a escola e a alfabetização, novas maneiras de conceber a relação entre os desenhos e seu suporte material foram introduzidas nas comunidades. As crianças indígenas aprenderam a contar histórias por escrito ilustrando-as com imagens pintadas sobre papéis e telas estendidas e fixas, fazendo quadros. Desse modo, elas começaram a experimentar um novo tipo de artefato visual, as pinturas, e descobriram que estas eram apreciadas pelos seus professores e pelas pessoas de fora. Um fator crucial para a aparição de artistas, isto é, de sujeitos plenamente dedicados a fazer pinturas, foi o apoio que eles receberam de pessoas dispostas a comprar e a difundir suas obras - professores, funcionários de organizações sociais, missionários, pesquisadores, antropólogos, turistas etc. Essas intermediações foram indispensáveis, pois incentivaram a dedicação dos jovens pintores, garantindo o retorno financeiro necessário para sustentar suas atividades. Outro fator determinante foi a disponibilidade dos jovens de viajar para as cidades e interagir com os meios culturais, especialmente em Lima (Chavarría 2012). 
Ainda jovens, Enrique Casanto e Roldán Pinedo saíram das suas comunidades de origem por alguns períodos para trabalhar em diversos ofícios. Posteriormente, eles viajaram para Lima com suas esposas e filhos em busca de emprego. Para ambos, a entrada nos circuitos culturais da capital aconteceu por meio da intermediação dos Talleres de Arte Popular do Seminario de Historia Rural (Oficinas de Arte Popular do Seminário de História Rural) da Universidade Nacional Mayor de San Marcos, dirigidos pelo historiador peruano Pablo Macera, que convocou a primeira geração de artistas indígenas amazônicos à cidade em meados da década de 90 . O apadrinhamento de Macera introduziu Pinedo e Casanto em relações de trabalho que, apesar das limitadas condições econômicas, lançaram suas carreiras artísticas. Outros pintores amazônicos convidados a fazerem parte das oficinas foram: Elena Valera (Shipibo-Konibo), nessa época casada com Roldán Pinedo; Victor Churay (1972-2002, Bora); Lastenia Canayo (Shipibo-Konibo); Robert Rengijo (Shipibo-Konibo); Santiago Yahuarcani (Uitoto) e seu filho Rember Yahuarcani. Todos eles desenvolveram técnicas e estilos de pintura próprios e, atualmente, fazem parte de uma geração de artistas indígenas que logrou um reconhecimento inédito em Lima (Macera et al. 2010).

Macera lhes fornecia materiais de pintura e pedia em troca que pintassem as histórias de seus povos e os mundos dos seus xamanismos. Ele incentivava a utilização de suportes e tintas naturais da selva e deixava que os artistas desenvolvessem os temas sugeridos livremente. Além disso, os quadros deveriam ser acompanhados por textos curtos que narrassem por escrito os conteúdos cosmológicos e históricos desenvolvidos visualmente. Os artistas recebiam um pagamento por cada obra realizada. O dinheiro obtido no final do mês lhes permitia viver modestamente com suas famílias, cônjuge e filhos, nos bairros de baixa renda do centro e da periferia de Lima. Foi assim que os pintores da floresta estrearam na capital: pagos para dar forma na tela à memória e aos seres das cosmologias ancestrais, para que pudessem ser vistos, lidos e colecionados pelos pesquisadores, não indígenas, da arte popular. A necessidade de vender suas telas para se manterem na cidade levou-os a procurar novos compradores, dirigindo-se principalmente ao pessoal das instituições relacionadas à Amazônia e a vendedores de artesanato especializado. Este público reconheceu desde o início que se tratava de obras únicas, cuja venda não devia ser absorvida pelo grande mercado do artesanato peruano, dirigido ao turismo massivo e dominado por produtores andinos.

Em 2000, Macera e a curadora de arte peruana Gredna Landolt organizaram uma exposição no centro de Lima, intitulada El ojo verde (O olho verde), que incluía uma extraordinária coleção de objetos da cultura mate- 
rial amazônica e obras dos novos pintores, tanto dos artistas do entorno de Macera como de alguns professores indígenas do programa de Formação de Professores Bilíngues da Amazônia Peruana - Formabiap (Landolt 2000). A mostra atraiu numerosos visitantes e despertou o entusiasmo dos meios de comunicação pelas artes da floresta, até então praticamente ignoradas devido ao foco predominantemente andino dos círculos folcloristas nacionais. A partir desse momento, os jornais e os programas de rádio e televisão em Lima mostraram-se favoráveis a difundir o trabalho dos pintores amazônicos.

O interesse no Peru confluiu com o sucesso, no exterior, de Pablo Amaringo (1938-2009), cuja obra foi difundida internacionalmente pelo antropólogo Luis Eduardo Luna (Luna \& Amaringo 1991). Amaringo se apresentava principalmente como um ribeirinho mestiço, mas também reconhecia sua origem indígena Kechua Lamista e tinha grande familiaridade com o xamanismo cocama e shipibo-konibo da região do Ucayali. Entre 1988 a 2009, ele conduziu na cidade de Pucallpa, capital do Ucayali, a escola de pintura Usko Ayar dirigida a alunos locais, principalmente mestiços. Até hoje seus alunos carregam seu estilo distintivo e continuam a difundi-lo (Bendayán \& Villar 2013b). Suas telas espetaculares mostram o inesgotável universo imagético de suas experiências visionárias geradas pela ingestão das "plantas com poder", também chamadas "plantas mestras", como o tabaco, a ayahuasca (Banisteriopsis caapi) e o toé (Brugmansia sp.). Embora sua obra pioneira tenha tido influência nas pesquisas de Macera, ela não foi muito promovida em Lima, pois seu público comprador era principalmente composto por estrangeiros envolvidos em movimentos new age. Ainda assim seu sucesso internacional nas artes visionárias teve um impacto, mesmo que indireto, sobre os artistas indígenas em Lima, pois impulsionou o turismo xamânico estrangeiro na Amazônia peruana. Por sua vez, o auge do turismo facilitou a chegada ao país de potenciais compradores das obras dos pintores indígenas.

Sendo assim, os pintores amazônicos em Lima conquistaram aos poucos certa viabilidade econômica, embora com rendimentos modestos, por meio da convergência de diversos públicos. Por um lado, um público principalmente peruano, limenho, de pessoas interessadas em etnologia, história e arte indígena; por outro, um público em sua maioria estrangeiro ligado ao turismo xamânico. Progressivamente, outros públicos foram conquistados. Após o massivo protesto indígena contra as mudanças legislativas do governo de Alan García Pérez e o violento despejo dos manifestantes awajún e wampis pelas forças policiais em Bagua, em junho de 2009, os pintores indígenas adquiriram uma nova relevância política. O aumento das exposições, dos colóquios e das publicações sublinhou a presença amazônica na capital e em outras cidades do país, fazendo de 2009 "um ano amazônico", como 
apontou o artista iquitenho Christian Bendayán. Nos jornais, no rádio e na televisão, a opinião política dos novos pintores começou a ser valorizada, o que contribuiu para posicioná-los no cenário intelectual limenho, sendo reconhecidos pela academia como "intelectuais indígenas" (Burga 2009). Cabe mencionar que, apesar da vitalidade da produção pictórica, os rendimentos dos pintores são precários, pois as vendas das telas são esporádicas e os preços variam dependendo do comprador e da urgência do vendedor. Eles conseguiram se posicionar nos meios de comunicação, no país e no exterior, mas ainda precisam se colocar nos circuitos comerciais das galerias nacionais e internacionais.

\section{Roldán Pinedo - Shoyan Sheca}

"Esta cor marrom é o motivo da selva". Com essas palavras, Roldán Pinedo me apresentou suas telas, quando fui entrevistá-lo pela primeira vez em 2007, em sua pequena casa-oficina em Cantagallo, no centro de Lima, onde morava junto com outras famílias shipibo-konibo que haviam migrado para a capital. A cor marrom vem de corantes naturais e serve para preencher o fundo de suas imagens. O procedimento de tingimento das telas é o mesmo usado pelas mulheres nas comunidades do Ucayali para tingir os tecidos em que bordam e pintam delicados grafismos kene. O pano de algodão cru, comprado na loja, é deixado de molho numa decocção de casca de mogno (Swietenia macrophylla) e, em seguida, secado ao sol. A operação pode se repetir várias vezes, até que se obtenha uma cor marrom escura. Nas pinturas já prontas, o fundo marrom com matizes mais ou menos claros ou avermelhados mostra-se como um chão abrangente que potencializa as cores dos traços desenhados sobre a tela.

“Eu trabalho assim, com muitas tintas naturais, para mostrar de onde venho", me explicou Pinedo. Originalmente, não apenas o marrom da tela, mas todas as cores de seus desenhos vinham da Amazônia. Eram índices materiais das roças, dos rios e das florestas onde foi criado: urucum para o vermelho e o laranja, açafrão da terra para o amarelo, jenipapo para o azul cinza, e vários tipos de terras coloridas para o branco, o creme, o ocre e o negro. "Inspirei-me em minha avó para fazer minhas tintas. Ela utilizava plantas e barro para pintar suas cerâmicas e seus panos", me disse, reconhecendo sua dívida com as mulheres que guiaram sua iniciação nas artes gráficas. Para ele, pintar na cidade é uma maneira de dar continuidade às técnicas visuais ancestrais e de reafirmar sua relação com o território de origem no Ucayali. Porém, após morar 15 anos em Lima, ele começou a usar 
acrílicos em suas pinturas e, às vezes, a deixar a tela de fundo branca sem tingir. Esta mudança nos materiais deveu-se, por um lado, às dificuldades de obter os corantes e os barros da floresta e ao custo de transportá-los até Lima e, por outro, à evolução da sua relação com a cidade. "Agora Lima é também um pouco minha selva", ele me disse. "Eu também preciso usar os materiais que a cidade, como a floresta, me dá".

Pinedo herdou seu nome shipibo-konibo, Shoyan Sheca, "Camundongo Inquieto", de seu avô que era um renomado xamã ayahuasquero. Ele cresceu na comunidade de São Francisco de Yarinacocha e chegou a Lima no final dos anos 80 com sua esposa, Elena Valera, também pintora. Depois de um tempo morando na periferia, em 2000, juntou-se a outras famílias shipibo-konibo para fundar um bairro indígena amazônico em um lixão no centro da cidade, batizado de Cantagallo. Foram anos de luta das associações de moradores indígenas para conseguir moradia estável e escola para seus filhos na cidade. Além de vender suas pinturas, o casal vivia da venda de artesanato nas ruas de Lima e de empregos ocasionais. Ainda hoje a luta pela moradia continua, já que o lixão se encontra numa área onde a Prefeitura de Lima planeja desenvolver um projeto de revitalização urbana que contempla a remoção dos habitantes (Castillos Torres 2013:75-84).

O casal deu junto os primeiros passos na pintura, quando ambos trabalhavam para Macera. Posteriormente, eles se separaram, mas o estilo de Roldán ainda deve muito aos ensinamentos de Elena. No começo, era ela quem desenhava as figuras e os grafismos dos quadros, e ele só colocava a cor. A ideia de tornar-se um homem desenhista não correspondia às suas expectativas pessoais, já que desenhar é uma atividade usualmente feminina entre os Shipibo-Konibo. Mas aos poucos ele foi aceitando a mudança e começou a traçar suas próprias imagens e grafismos (Castillos Torres 2013:121).

Os desenhos femininos têm uma presença-chave na obra de Pinedo. É preciso, portanto, descrever brevemente sua composição. Como assinalei acima, os grafismos shipibo-konibo não procuram imitar as imagens dos corpos sobre uma superfície, e sim cobrir a superfície do volume de um corpo ou de um artefato com redes, ou "cercas" de desenhos geométricos chamados kene (Illius 1992, 1994; Gebhart-Sayer 1985). O primeiro passo para pintar desenhos é traçar uma moldura numa superfície, geralmente o contorno de um retângulo. Depois, a superfície no interior da moldura é progressivamente preenchida com circuitos de linhas de diferente grossura até saturar o espaço. O resultado final é uma malha de linhas que dá uma impressão de profundidade e movimento interno, devido à superposição das camadas e ao contraste entre as linhas pintadas e os espaços em branco (Belaunde 2013b). 
Para os Shipibo-Konibo, esses desenhos não são meras expressões gráficas das mulheres, mas materializações da "energia" ou "força" koshi das plantas, especialmente das plantas rao, um termo traduzido em espanhol como "planta com poder" ou "medicinal". Essas plantas são consideradas poderosas porque elas têm ibo, um conceito que os Shipibo-Konibo normalmente traduzem em espanhol como "dono" ou "mãe". As mulheres tornam visível a energia das rao nos grafismos sobre os corpos e os artefatos, mas a força das plantas também pode se manifestar em visões intangíveis, sem um suporte material como, por exemplo, durante a ayahuasca, chamada nishi (cipó) em shipibo-konibo. Além disso, os desenhos podem aparecer em sonhos por meio do uso de outras plantas, chamadas waste em shipibo-konibo e conhecidas como piri piri em espanhol regional.

Os piri piris pertencem à espécie das cyparaceas e têm um amplo leque de utilidades. O etnobotânico Tournon (2006:73) as descreve como "etotropos", isto é, como plantas usadas para afetar o comportamento das pessoas para diversos propósitos como produzir visões de kene, aguçar a visão, atrair amantes, acalmar ou vencer os inimigos, controlar a fertilidade e favorecer o crescimento das crianças. São plantas de grande importância ritual, mas sobre as quais se sabe relativamente pouco, justamente porque seu uso ritual requer manter o segredo. Os piri piris bem como a ayahuasca possibilitam comunicar-se com nishi ibo, "dono da ayahuasca" e dos desenhos. Este ser primordial também é chamado yacumama, "mãe das águas", uma expressão emprestada do quéchua que assinala a relação entre a jiboia, os desenhos e os fluxos dos rios. Desde pequenas, as meninas são curadas com uma variedade de piri piri para obterem visões de kene.

A palavra "curar" em espanhol é usada pelos Shipibo-Konibo para traduzir conceitos indígenas que ultrapassam os significados do termo em espanhol ou português. "Curar" é utilizado como tradução de benxoti, no sentido de "sarar", e também como tradução de raonai, no sentido de "usar plantas rao". Neste último caso, curar também significa preparar uma pessoa para que possa exercer suas capacidades plenamente e colocar dentro do seu corpo, por meio de rituais, elementos xamânicos de proteção contra possíveis doenças e ataques espirituais. Agustina Valera, renomada desenhista, moradora de São Francisco, a comunidade de nascimento de Pinedo, explica que as nervuras das folhas do piri piri usado para curar o umbigo e os olhos são semelhantes aos desenhos kene:

Há também um piri piri para aplicar nos olhos. Ele se encontra nos terrenos inundáveis, suas folhas têm desenhos iguais aos que nós fazemos, com pontinhos que vão formando figuras e traços. Para aprender a desenhar, ferve-se 
o piri piri e os olhos são curados com seu vapor [...] Quando nós curamos os olhos com piri piri, temos sonhos. Sonhamos que estamos no meio de desenhos elegantes e resplandecentes. Às vezes, trabalhamos com o espírito do piri piri de noite, desenhamos em nosso sonho. Outras vezes, vemos as yacumamas. Isso não acontece simplesmente assim, deve-se ao piri piri com o qual fomos curadas. O fato de aprender com piri piri não é nada novo, nós temos piri piri desde os tempos antigos (Valenzuela \& Valera 2005:65-66).

A variedade de folhas cujas nervuras são associadas aos desenhos na pele do peixe ipo (carachama, Panaque schaeferi) é particularmente usada para preparar a visão das mulheres. Portanto, o processo de transmissão dos desenhos por meio da cura do umbigo e dos olhos das mulheres se funda numa série de semelhanças estabelecidas entre os desenhos da superfície de diferentes seres. Alguns desenhos são observáveis no entorno da selva e dos rios, como os desenhos de peixe ipo, das folhas do piri piri e das jiboias; mas outros são captados só em visões, como os desenhos do "dono" e "mãe" primordial dos desenhos, da ayahuasca e das águas, que contêm todos os desenhos possíveis. A observação dos desenhos visíveis no entorno é um mecanismo importante de aprendizado, mas a capacidade de ver desenhos em visões é o que caracteriza as mulheres consideradas exímias desenhistas. Elas não precisam copiar os desenhos, pois os veem em xinan, "pensamento".

A preparação ritual com piri piri também fornece às mulheres uma poderosa arma de sedução para o amor. Segundo os homens shipibo-konibo, as mulheres que sabem perceber desenhos em visões os hipnotizam com a armadilha dos desenhos pintados e bordados em suas saias. Elas são experientes caçadoras de homens e sua arma é a paixão que inspiram. É claro que os homens não ficam atrás no jogo da sedução e também são curados com piri piri na puberdade, não para fazer desenhos com maestria e sim para atirar com pontaria. Pinedo, por exemplo, foi curado por seu avô paterno para pescar com tiro certeiro. Falando dos efeitos do piri piri, ele me contou que seu desejo de criança era ter sucesso na pescaria porque, desse modo, obteria o amor das mulheres e a aceitação de seus futuros sogros.

Fizeram-me piri piri para pescar. Quando criança, eu gostava de pescar, acompanhando meu avô, pescar jaú (Zungaro zungaro). Para ser bom pescador, você deve ser curado. Quando não está curado, traz poucos peixes, e não é suficiente para a família. Quando está curado, você traz bastante peixe. As mulheres te procuram. Elas querem casar com um bom pescador, e tua sogra fica feliz com os peixes. 
Na divisão das habilidades pessoais características das expectativas de gênero shipibo-konibo, uma exímia mulher desenhista é o equivalente a um homem pescador bem-sucedido. Ambos têm uma visão precisa e sabem capturar suas presas para o alimento e o amor. O jaú que Pinedo gostava de pescar é uma presa grande e, tradicionalmente, caçada com flecha e arpão. O pescador precisa medir a refração da luz para acertar sua presa na água. A cura com piri piri, portanto, visa produzir corpos com pontaria certeira para ambos os gêneros. A destreza visual desenvolvida nas artes gráficas e na pescaria sustenta o jogo da sedução no casal.

A palavra "curar" em espanhol também é utilizada para referir-se à ação dos xamãs, chamados onaya, que utilizam plantas para sarar, preparar ritualmente e dar proteção espiritual aos seus pacientes. Porém, é necessário que ele cumpra períodos prorrogados de resguardo para obter tais poderes. A maioria dos curandeiros são homens, mas as mulheres também podem praticar o xamanismo quando fazem os resguardos adequados (Colpron 2005; Herbert 2010; Belaunde 2015a). Durante esses períodos beberagens de plantas são ingeridas, mantém-se abstinência sexual e evita-se comer sal, doces e alimentos gordurosos. Dessa maneira, consegue-se sonhar com os ibo das plantas, recebendo guias e conselhos que habilitam o aprendiz a conduzir sessões xamânicas. Depois, durante as sessões de ingestão de ayahuasca cozida com chackruna (Psychotria viridis) e outras plantas, a "mãe da ayahuasca" aparece em visões para o xamã na forma de jiboias serpenteantes com a pele coberta de kene brilhoso. Os desenhos da sua pele também se encontram nos seres da floresta e dos rios, desde os menores, como as nervuras das folhas, até os maiores, como os caminhos do céu estrelado. Entende-se que a energia corre pelas linhas dos desenhos concentrando-se nas suas pontas, onde o xama, a "potência acumulada", faz brotar novos desenhos.

Não pretendo me aprofundar nas "terapias estéticas" shipibo-konibo (Gerbhart-Sayer 1985:145). O ponto que desejo salientar é que existe o consenso entre praticantes shipibo-konibo e pesquisadores de que, durante as sessões xamânicas, a cura dos participantes é efetuada por meio dos cantos do xamã e das visões de desenhos intangíveis que se apresentam após o cumprimento dos resguardos (Leclerc 2003; Illius 1992:66). Um paciente doente, mal disposto ou raivoso aparece rodeado de "maus ares escuros", enquanto uma pessoa sadia, corporal, social e espiritualmente tem ares perfumados e está coberta de desenhos de luz colorida. Os pacientes que mantêm abstinência sexual antes da sessão de ayahuasca também podem conseguir ver os desenhos que envolvem os corpos. O próprio Pinedo experimentou os efeitos visionários da energia das plantas: 
Quando você respeita a dieta, a mãe da ayahuasca te mostra tudo resplandecente. É uma mistura de duas plantas, a ayahuasca dá a mareação e a chackruna dá o brilho. Quando o maestro ayahuasquero é um poderoso curandeiro, a mãe da ayahuasca aparece, e você vê as escamas da anaconda brilhando. Você vê o curandeiro rodeado de desenhos coloridos. Ele tem suas arcanas de proteção, tem suas aves mensageiras, tem suas borboletas. Por isso eu completo meus quadros pintando as folhas da chackruna, com suas nervuras que trazem o brilho. Dentro da mareação, a ayahuasca te avisa como fazer. Eu não invento nada.

O sobrevoo nas práticas indígenas nos permite contextualizar a obra de Pinedo com referência às artes femininas e ao xamanismo. Tanto no caso da cura dos olhos das mulheres desenhistas com piri piri quanto naquele da cura dos participantes nas sessões de ayahuasca, a questão da luminosidade que emana das redes de desenhos que se apresentam em visões é central. O kene enquanto um agente estético e terapêutico visual é uma técnica de luz. As ideias de "resplendor" e "brilho", que correspondem aos termos pene e biri na língua indígena, são centrais às concepções shipibo-konibo sobre o modo como as visões de desenhos agem sobre as pessoas e em seu entorno, dando-lhes proteção espiritual.

Pinedo explica que quando foi convidado por Pablo Macera para participar dos Talleres de Arte Popular del Seminário de Historia Rural, ele percebeu a necessidade de retomar os ensinamentos que seu avô lhe havia transmitido antes de morrer. Sendo assim, ele viajou pelas comunidades do Ucayali e ingeriu ayahuasca. Para ele, foi a própria planta que o "avisou" como fazer a sua nova pintura.

Meu avô era curandeiro poderoso. Transformava-se, desaparecia e reaparecia. Ele era um meraya, aquele que se transforma em onça. Mas como morreu quando eu era menino, eu só tinha tomado ayahuasca uma vez antes de ir morar em Lima. Quando comecei a trabalhar com o historiador Pablo Macera, aí comecei a levar a sério o meu avô, porque se veem muitas coisas em visão, coisas que devemos fazer nas nossas vidas. A própria planta nos guia; é assim mesmo. Tomei plantas com o tio da minha esposa. Eu pinto o que vejo: as borboletas que nos cuidam e os olhos com desenhos pintados em suas asas; as aves mensageiras que avisam o curandeiro; a sereia encantadora que ajuda que a mulher seja amada; o fumo que protege. Tudo é brilhoso, tudo tem seu desenho kene, sua energia para jogar fora as coisas negativas, para curar.

A singularidade da técnica pictórica de Pinedo reside nos grafismos que cobrem os corpos que ele representa figurativamente. Seu uso da figuração concentra-se nos contornos das figuras, mas esses contornos, por sua vez, 
servem de molduras preenchidas com desenhos. A figuração, portanto, é colocada em função dos grafismos. Os desenhos no interior das figuras são bem mais salientes do que as linhas dos contornos das mesmas figuras; e como cada figura-moldura na tela está preenchida com desenhos diferentes, o conjunto da tela está saturado de diversidade e de contrastes entre claros e escuros, fundos e figuras. Esses jogos de luz atraem e confundem o olhar, gerando uma impressão de movimento incessante. Além de usar desenhos kene, Pinedo preenche suas figuras com detalhes figurativos que também se destacam bem mais do que a linha dos contornos das figuras. Por exemplo, ele acentua as nervuras das folhas, as linhas do penteado das penas dos pássaros, as pintas das peles dos animais, o filo das escamas dos peixes e as curvas da trajetória dos rios. Nesse sentido, seu estilo pictórico explicita a relação, implícita na arte feminina, entre os desenhos kene e as manchas da pele dos animais, as nervuras das folhas e os caminhos dos rios. A roupa dos xamãs, a cauda das sereias e a pele das jiboias, todas elas têm seus próprios enfeites geométricos ou figurativos, que enchem as telas de contrastes de luz.

Sendo assim, a originalidade de Pinedo não consiste somente em representar figurativamente o mundo visionário do xamanismo de seu avô, mas em trazer para a tela essa energia koshi que ele viu em visões durante as sessões xamânicas, e em presentificar a luminosidade biri curativa das plantas. Sua inovação pictórica reside nas técnicas de visibilização do brilho que ele aprendeu com sua primeira esposa Elena Valera e as quais ele transformou a partir de suas visões de ayahuasca. Porém, sua criatividade não é produto unicamente da sua subjetividade; ela não se limita à sua autoria nem aos conhecimentos que ele aprendeu de seu avô e demais ancestrais. Para o pintor, a criatividade provém das plantas que o "avisaram" como pintar; do piri piri e da ayahuasca, e de seu "dono" ou "mãe" cuja energia perpassa o artista para se manifestar em suas obras. Os efeitos de luz de suas pinturas estão fundamentados no caráter testemunhal de suas imagens e agem no mundo com a força das plantas, seduzindo o público, capturando-o e emanando proteção: “Tudo o que se vê em visões está coberto de desenhos. Tudo tem seu kene, é sua energia, sua medicina. Bem bonito, bem brilhante. Tudo é brilhoso. Meus quadros dão proteção. A própria planta me avisou. Eu pinto o que eu vi". 


\section{Enrique Casanto - Guerreiro Orquídea}

"Orquídea", este é o significado de "Casanto", o nome do grupo familiar Ashaninka do rio Kokari, na Selva Central, ao qual Enrique pertence por linha paterna. Ele se orgulha de fazer parte de uma família que se destaca por ter vencido a guerra usando as armas de uma flor. "A sabedoria da orquídea", ele me contou, "consiste em passar despercebida na folhagem, grudada aos troncos da floresta. O guerreiro esconde-se do olhar dos seus inimigos, assim transformado por um tempo e, depois, volta para o ataque sob a forma de pessoa, e no momento menos esperado os vence". Essa metamorfose em flor é a estratégia de guerra favorita de seus ancestrais, e que o artista perpetua por meio da pintura. Como no caso da beleza da orquídea, por trás do estilo pictórico de Casanto, prepara-se o ataque de um guerreiro conhecedor do passado indígena e disposto a defender o legado de seus ancestrais.

Quando ele foi convidado por Macera para fazer parte dos Talleres de Arte Popular del Seminário de Historia Rural, Casanto já tinha uma longa experiência como pesquisador próprio do mundo ashaninka. Ele estudou na escola adventista de sua comunidade e, depois, se formou como ajudante de enfermagem. Entre 1987 e 1993, trabalhou em hospitais e em comunidades indígenas, organizando campanhas de saúde na Selva Central. Durante esse tempo, as intervenções do Sendero Luminoso, do MRTA e dos militares peruanos chegaram ao ápice da violência nessa região. As famílias ashaninka sofreram violações extremas por parte da guerrilha e dos militares, incluindo deslocamento forçado, tortura, estupro, morte e escravidão. Em face da violência desenfreada, a atuação dos guerreiros ashaninka na libertação de seus parentes e a recuperação do controle de suas terras foi determinante. No dia 24 de fevereiro de 1989, 80 lideranças ashaninka se reuniram e anunciaram a criação do "Exército Ashaninka". Sua vitória, entretanto, não foi completa. Vinte cinco anos depois, algumas famílias continuam reféns da guerrilha remanescente no Vale dos rios Apurimac e Ene (VRAE), onde a economia está atualmente regida pela produção de cocaína para o tráfico internacional. As consequências do conflito armado ainda são drásticas. Estima-se que de uma população de 50 mil ashaninkas, 10 mil foram deslocados forçadamente, 5 mil foram mantidos em cativeiro, 6 mil pereceram, e desapareceram mais de 30 comunidades (Espinosa 1993:80-82; Comisión de la Verdad y la Reconciliación, vol. V:241-244).

Casanto viveu esses anos terríveis no fogo cruzado entre os três bandos, já que tanto os militares como os guerrilheiros do Sendero Luminoso e do MRTA frequentavam os postos de saúde onde ele atendia os doentes e feridos. Ele sofreu constantes ameaças e extorsões por parte dos guerrilheiros que exigiam que ele lhes entregasse seus filhos menores: 
Eles (Sendero Luminoso) diziam: o povo vai executar um ladrão! E nós víamos que a pessoa não era um ladrão, não era um mentiroso; simplesmente eles matavam para nos atemorizar, para que os Ashaninka não pensassem em fugir. Eles vinham se tratar no posto de saúde onde eu trabalhava e me diziam; "Casanto, você tem dois filhos, queremos que eles venham conosco!". "Mas são crianças, não sabem nada", eu me negava a entregar meus filhos. "Amanhã vamos matar você, você tem que dar!", mas eles não podiam me matar porque precisavam de mim no posto de saúde.

Foi nesse tempo de luta que ele aprendeu dos anciãos o conhecimento das plantas, especialmente do tabaco, chamado sheri, a planta principal dos sheripiari, isto é, dos xamãs "tabaqueiros", e também de plantas chamadas benki em ashaninka e piri piri em espanhol regional. Assim como os piri piris dos Shipibo-Konibo, os piri piris dos Ashninka são plantas cyparaceas, com diferentes variedades para um vasto leque de usos. O próprio Casanto produziu um livro ilustrado, intitulado Piri piris: Plantas medicinales de la Amazonia, que contém as histórias, os usos e as pinturas de mais de 20 plantas benki que os anciãos lhe ensinaram (Casanto 2005).

Ele explica que depois da chegada dos missionários adventistas na Selva Central, nos anos 20 do século passado, o uso dos piri piris para a guerra havia sido deixado de lado. Continuava-se usando os piri piris para preparar as meninas para a tecelagem e os piri piris para aguçar a pontaria dos meninos caçadores, mas as plantas para a guerra haviam sido esquecidas porque não havia mais enfrentamentos entre ashaninkas, nem mesmo contra os colonizadores: "Quando chegaram os adventistas, deixamos de fazer guerra entre famílias ashaninka. Os jovens não estavam mais interessados em aprender". Mas a extrema violência sofrida nas mãos da guerrilha e dos militares levou os jovens, incluindo o próprio Casanto, a convocar os anciãos para pedir que lhes ensinassem os segredos dos benki da guerra. Esses conhecimentos logo foram colocados em prática para libertar os seus parentes.

A subversão nos fez voltar para o uso das plantas. Nas comunidades ashaninka a gente diz: "nossos antepassados tinham plantas para fazer chover, para fazer vento, para fazer o rio crescer, para deixar as pessoas zonzas, precisamos recuperá-las!". Os jovens falaram com os velhos: "você sabe isso, você sabe fazer dormir as pessoas, vamos ver como podemos usar isso!". Muitos chefes se reuniram e concordaram em ensinar para os jovens. E os jovens falaram: "agora vamos provar se é certo!". Então nós, os jovens, começamos a fazer o trabalho dos anciãos porque havíamos aprendido deles. 
Desse modo, ele aprendeu as estratégias do inkanibenki (piri piri da chuva), do tampiabenki (piri piri do vento) e do ocastarobenki (piri piri do raio): "Mastigamos o piri piri pensando no efeito que desejamos. Quando começa a ventar, os inimigos voltam pra casa para se resguardar da tempestade torrencial e, nesse momento, nós rodeamos eles e atacamos". O sucesso do empreendimento, entretanto, depende da preparação do guerreiro e sua esposa, já que ambos devem manter abstinência sexual durante um período depois de mastigar as plantas. Se eles não cumprirem o resguardo, as plantas não farão efeito ou poderão virar contra quem as utiliza. A abstinência sexual também é requisito para aprender a contatar o espírito "dono", ashitariri, do tabaco e, através dele, contatar os ancestrais. "Quando você bebe tabaco, o tabaco te ensina como uma avó", ele explica. O tabaco conversa e instrui pessoalmente o aprendiz, mas exige abstinência sexual.

Quando você consegue passar [n]as provas que o tabaco te coloca, você também consegue contatar os guerreiros do passado e aprender o uso das plantas benki com eles. Você toma tabaco e o tabaco te pergunta:

- "Filho, o que você quer de mim?"

- "Eu quero aprender as plantas medicinais para curar minha gente".

- "Mas primeiro você precisa fazer uma dieta. Você tem esposa. Vai e diga para sua esposa que ela vai ter uma irmã; que você vai ter outra esposa, não carnal, mas espiritual. Sua esposa tem que aguentar nove meses sem ter relações sexuais com ninguém. Se ela aceitar, volta para mim. Você também não pode ter relações sexuais durante nove meses. Se você ou sua esposa quebrar o resguardo, você não será curandeiro. Você vai virar bruxo e vai trazer doenças para as pessoas ao redor".

Casanto aprendeu a beber tabaco com um primo de seu pai e, desse modo, conseguiu contatar os grandes ovayeri, "guerreiros", do passado. Esses ancestrais, ele explica, são os fundadores dos grupos familiares apatoitaantso ashaninka, um conceito que ele traduz como "clãs", que até algumas décadas atrás estavam distribuídos ao longo dos rios da Selva Central. Segundo Casanto, esses guerreiros destacaram-se pelas suas destrezas na época de Juan Santos Atahualpa, a liderança do povo Ashaninka e de outros povos da família linguística Arawak do sopé andino, que conduziram uma rebelião contra os espanhóis no século XVIII, sobre a qual existem registros da época colonial (Casanto 2009; Santos \& Barclay 1995; Brown \& Fernandes 1991).

Os estudos históricos sugerem que, provavelmente, Juan Santos Atahualpa foi um mestiço andino procedente de Cuzco, considerado descendente do inca Atalhualpa. Sua rebelião reuniu os povos Arawak e mudou a configuração política do sopé andino. Devido a seus constantes ataques, 
as zonas alto-andinas habitadas por grupos falantes de quéchua foram fechadas pelas forças da Coroa espanhola para evitar que os indígenas das terras baixas tivessem acesso aos bens comerciais que circulavam nos Andes. Mas os seguidores de Juan Santos continuaram conduzindo expedições à procura de armamentos de ferro e outros produtos coloniais. Os últimos registros de ataques datam de 1752. A partir de então, os documentos são escassos e os relatos passam pelas narrativas dos descendentes daqueles que se mantiveram em guerra durante quase um século, conseguindo que a região da Selva Central resistisse às entradas coloniais até o ano de 1847, quando as políticas de colonização da nova república peruana promoveram a chegada de migrantes europeus e peruanos nas suas terras (Brown \& Fernandes 1991:36-43; Santos \& Barclay 1995:48-50).

As pinturas de Casanto, inicialmente feitas com pigmentos naturais e, posteriormente, com têmperas no papel, ou acrílicos na tela, contam através de imagens as versões da guerra que ele aprendeu dos anciãos e dos ensinos do tabaco. Suas composições figurativas mostram os guerreiros dos diversos clãs unidos contra os espanhóis em torno de Juan Santos Atahualpa, mas também se enfrentando uns contra os outros. Cada guerreiro é caracterizado por sua estratégia de guerra, que consiste em transformar-se em algum ser, seja uma planta, um animal, um peixe ou uma ave, para vencer seus inimigos e, assim, apoderar-se de suas mulheres e seus territórios. A transformação de humano em não humano, e vice-versa, era possibilitada por seus conhecimentos do tabaco e dos piri piris e pelo respeito ao resguardo. A proximidade ritual com as plantas tornava os ancestrais invencíveis. Mas essa ambição, que Casanto qualifica de "soberba" ou "orgulho" - sua tradução do termo kishingari - levou-os ao "castigo", piyatsari, já que outros tabaqueiros se uniram contra aqueles que acumularam mulheres em excesso e os transformaram em seres da floresta de maneira definitiva. O fim da reversibilidade das transformações foi a sina de todos os guerreiros ancestrais. Por exemplo, o ovayeri Casanto, o "Guerreiro Orquídea", fundador do clã Casanto, foi convertido em orquídea da seguinte maneira:

Casanto tinha um cocar feito de penas de arara e duas penas de Galo da Serra (Rupicola peruvianus) indicando sua menor hierarquia. Ainda que ele tivesse muito poder, ele não era o chefe dos chefes e precisava esperar que seu pai morresse para ocupar seu cargo. Quando Casanto lutava contra os espanhóis, ninguém podia encontrá-lo, porque ele se escondia num tronco de árvore podre, ele parecia uma orquídea inofensiva. Depois da morte de seu pai, ele virou chefe dos chefes e exerceu o poder. Então, ele se casou com muitas mulheres de diferentes vales. Os outros chefes ashaninka ficaram atemorizados e o convidaram 
para participar de uma reunião onde eles iriam dividir o poder. Mas Casanto, cheio de orgulho, não aceitou. Em vez de atender ao pedido dos outros chefes, ele começou a tramar como matá-los. Então os outros chefes concordaram que precisavam transformá-lo em alguma coisa, e assim fizeram. Uma vez, durante um enfrentamento com seus inimigos, Casanto foi esconder-se como ele sempre fazia. Ele virou uma orquídea pendurada no tronco de uma árvore para que ninguém o reconhecesse. Mas quando tentou voltar para a sua forma humana, ele não conseguiu e ficou convertido em orquídea (Casanto 2002:13).

Os antigos guerreiros transformados definitivamente em seres da floresta deixaram como legado o nome dos clãs, que depois viraram os sobrenomes atuais e são herdados por linha paterna. De acordo com Casanto, até hoje, os tabaqueiros que respeitam o resguardo sexual podem contatar os ancestrais guerreiros em visões e em sonhos e voltar a utilizar suas estratégias de guerra quando precisarem. Além de compartilharem um mesmo ancestral guerreiro, os membros de um clã estão unidos ao ser da floresta que lhes dá o sobrenome pelo destino pós-mortem. Por exemplo, o destino de Enrique, assim como o de seu pai recentemente falecido, é transformar-se em orquídea

Antes de morrer, quando já estava bem doente, meu pai, Odiseo Casanto, disse para meu irmão: "no dia em que eu morrer, eu vou virar uma orquídea. Assim, você sempre me verá nessa orquídea. Eu não vou para o céu, eu vou crescer, eu vou crescer numa planta". "Papai diz que ele vai crescer, está maluco!", dizia meu irmão. Mas depois da sua morte, uma orquídea apareceu numa árvore perto do cemitério de Shuringaveni. O tabaqueiro falou: "ninguém pode mexer nessa orquídea porque ela tem dono. Se alguém pegar ela, vai adoecer ou vai morrer, porque essa orquídea é um avô do clã Casanto".

As pinturas de Casanto tornam visíveis para um público não indígena as histórias de transformação das estratégias guerreiras, que foram reatualizadas na luta contra a guerrilha e ainda continuam vigentes. Em suas telas, ele cria formas que poderiam ser descritas como híbridas, resultantes da junção de pedaços de corpos provenientes de diferentes seres, humanos e não humanos. Seus retratos dos ancestrais mostram corpos feitos de uma metade humana e de outra não humana: um braço, uma perna e parte do rosto são de gente; o outro braço, a outra perna (não necessariamente simétrica) e o resto do rosto são de outro ser. Não obstante, o conceito de híbrido não corresponde à concepção de Casanto pois, para ele, suas pinturas atestam a existência das capacidades de transformação dos seus ancestrais, que ele conheceu e viu graças aos ensinos dos anciãos e do tabaco. O elemento que 
identifica suas personagens é a vestimenta: a túnica kitarentse, os colares de sementes e o cocar do tabaqueiro, com padrões de desenhos de tecelagem e feitura distintivamente ashaninka. Essa ênfase nas roupas que compõem a pessoa, e ao mesmo tempo manifestam seus poderes, é característica das práticas ashaninka de produção de corpos e artefatos (Beysen 2008:77, 2013).

A pintura do guerreiro Orquídea, por exemplo, com uma mão e um pé que parecem raiz, leva uma flor de orquídea roxa na cabeça e uma túnica de algodão comprida, com fitas brancas e cinzas. Seu arco e suas flechas estão ao seu lado, sempre atento para a guerra. "Eu pinto meus quadros porque vi os guerreiros. O tabaco me mostrou eles em visões e eu escutei as histórias dos anciões", afirma Casanto. Seu uso da figuração é um ardil para fazer seu público ver e entender as estratégias de guerra de seus ancestrais.

O doutor Pablo Macera me perguntava: "Mas por que você pinta assim, um pé de pessoa e outro pé de planta ou animal?". "Não é simplesmente porque eu quero desenhar, por exemplo, uma vespa com uma asa de inseto e uma mão de pessoa", eu lhe respondia. Eu pinto a vespa porque a vespa tem seu ninho e se você toca ele, imediatamente ela vem contra você e te pica. Não só uma vespa, mas muitas vespas vêm juntas atacar. Os antigos guerreiros que se transformavam em vespas eram muito rebeldes. Eles formavam grupos para lutar contra seus inimigos. Por isso eu pinto a história do ovayeri sani, o guerreiro vespa. Eles se transformavam porque eram grandes tabaqueiros.

Mais do que pintar corpos com formas híbridas, Casanto pinta as habilidades características de cada grupo familiar materializadas nas suas roupas e, também, nos seus armamentos e instrumentos: tecidos, trançados, cestos, armadilhas, flechas, lanças, canoas, casas, anzóis etc. Cada guerreiro tem sua própria túnica, seu cocar e ornamentos feitos com desenhos e cores que o singularizam. Seus instrumentos também são distintos e os detalhes dos artefatos reproduzidos apresentam fielmente os traços típicos ashaninka. A meu ver, este é um propósito central do seu uso inovador da figuração: apresentar em imagens a diversidade dos artefatos ashaninka associada aos clãs, pois seus retratos dos guerreiros são também reproduções imagéticas de suas tecnologias.

O tema do "castigo", a perda da capacidade de reverter a transformação e a subsequente separação entre humanos e não humanos abrem perguntas sobre a origem dessas tecnologias. Será que os artefatos, as roupas e os enfeites, os instrumentos e os armamentos vêm dos insetos, dos pássaros ou de outros não humanos? Ou, inversamente, será que esses seres da floresta os adquiriram dos antepassados ashaninka? As duas respostas são possíveis, pois bem mais do que tentar afirmar uma origem certa para os artefatos, 
a questão colocada pelas pinturas e pelos relatos de Casanto parece ser o fato de esses mesmos artefatos e tecnologias serem compartilhados pelos humanos e os não humanos; ou mais precisamente, o fato de esses artefatos e tecnologias serem afirmações de humanidade, pois eles constituem as habilidades ashaninka e definem os grupos familiares distribuídos pelos rios. Portanto, ao mesmo tempo em que as pinturas manifestam a diferença entre humanos e não humanos - ashaninka e seres da floresta - elas revelam a humanidade comum concomitante com suas diferenças.

Além disso, suas pinturas mostram que a paisagem da floresta e os seres que a povoam são investidos de inteligência, tanto para a proteção como para a ofensiva, e também para o ensino dos perigos das ânsias de poder. As telas e suas histórias contam como esses guerreiros abusaram da sua invencibilidade, o que os tornou vulneráveis, fazendo-os perder a capacidade de retornar à forma humana devido aos seus excessivos desejos de se destacarem e acumularem mulheres e território, não aceitando jamais concordar ou ceder. Eles foram vencidos pela união dos outros e, vale destacar, todos eles passaram por esse "castigo" e se tornaram seres da floresta. Contudo, as telas tornam visível para o público da cidade o quanto a selva contém um repertório extraordinário de estratégias bélicas, em que cada um ataca e se defende. Assim, a mensagem política é explicitada: fazer ver o meio da selva, os rios, o céu e todos os seres que os habitam como sujeitos plenamente inteligentes.

\section{Testemunhas da transformabilidade}

Apresentei aqui as trajetórias de dois dos maiores expoentes da nova pintura indígena na Amazônia peruana, tentando introduzir os elementos dados pelos próprios pintores para que possamos pensar sobre sua arte. Embora haja grandes diferenças de técnicas, estilo, materiais e temas entre os dois artistas, ambos se referem continuamente à eficácia das plantas do seu xamanismo, no caso de Roldán Pinedo, a ayahuasca; no de Enrique Casanto, o tabaco. Ambos também ressaltam a importância das plantas cyparaceas, chamadas piri piri em espanhol regional (waste em shipibo-konibo, benki em ashaninka), e manifestam que suas obras não têm como propósito somente a apreciação visual, mas visam revelar os conhecimentos dos ancestrais e causar um efeito naqueles que as apreciam.

Como argumentei anteriormente (Belaunde 2013a, 2011), a nova pintura indígena no Peru é usualmente associada aos rótulos da arte xamânica ou da arte visionária, mas constitui, mais especificamente, uma pintura tes- 
temunhal. São obras que narram visualmente as experiências pessoais do pintor ou de parentes que contaram suas vivências para o artista. Pinta-se aquilo que foi vivenciado em estado de vigília e também em sonhos e em estados xamânicos, assim como aquilo que foi observado ao redor, escutado dos anciãos ou aprendido com o uso ritual de plantas. Um ponto-chave é que os artistas pintam para um público citadino não indígena, nacional ou estrangeiro. Portanto, a produção de imagens requer um exercício criativo de tradução das formas de percepção e de narrativa ameríndias para as formas plásticas de uma nova pintura figurativa que possa ser enxergada pelo público não ameríndio. Além disso, o público-alvo das exposições e das vendas de obras compõe-se por pessoas interessadas tanto na Amazônia quanto nas artes plásticas, isto é, o valor das telas não reside somente em suas qualidades estéticas, mas nas pistas de acesso aos conhecimentos indígenas contidas na composição visual. Para o comprador, a aquisição de uma obra lhe permite levar para casa uma imagem por meio da qual busca uma aproximação com a alteridade radical da Amazônia materializada na tela.

O que é tornado visível nas telas de Pinedo e Casanto? O que elas mostram por meio da figuração para o público não indígena ver? Mais do que um mundo invisível ou escondido, suas pinturas fazem ver mundos em transformação. O uso criativo da figuração por ambos os artistas não pretende revelar formas concluídas e fixas, pois aponta para a transformabilidade dos seres. A figuração na pintura de Pinedo é um meio para apresentar e presentificar os efeitos de luz dos grafismos kene e o brilho curativo que se manifesta em visões e muda os seres, agindo sobre o mundo e curando o que está ao redor. $\mathrm{O}$ brilho que é tornado presente é a evidência e o meio de efetuação dessa transformação, portanto, as pinturas de Pinedo estão carregadas de um potencial curativo. A pintura de Casanto, no entanto, não presentifica a potência curativa do brilho. Para ele, a figuração permite apresentar, por um lado, o caráter duplo dos ancestrais como valentes guerreiros e como elementos vivos da paisagem da floresta. Por outro lado, ela acentua a humanidade associada aos artefatos e às tecnologias, comuns a humanos e não humanos. Há grandes diferenças entre ambos os pintores, mas tanto um quanto o outro pintam a transformação e, assim, afirmam imageticamente a fluidez das existências, o trânsito como o lugar privilegiado do olhar e do atuar xamânico e, também, da agência política indistinguível das interações sociocosmológicas mais amplas. Suas buscas experienciais, conceituais e estéticas desenvolvidas através da pintura são igualmente uma procura de técnicas imagéticas para derrubar o monopólio das imagens fixas e preconceituosas sobre os indígenas convencionalmente produzidas pelos não indígenas nas cidades. 
Els Lagrou (2007) propôs levar a sério a ideia de Alfred Gell (1998) de abordar a arte a partir das relações sociais no caso da arte ameríndia e desenvolveu um estudo da fluidez das imagens entre os Huni Kuin. O que a arte ameríndia faz? Num artigo instigante, a autora (2011) se interroga sobre quais seriam os atributos de uma arte que, como a dos povos indígenas amazônicos, não se submete à fixidez coercitiva do Estado. Respondendo ao chamado de Clastres para escapar do discurso da falta, que descreve o universo ameríndio pela ausência dos mecanismos sociais e epistemológicos europeus (2003 [1974]), Lagrou sugere inverter a ótica do colonizador e olhar para a arte ocidental tendo a perspectiva ameríndia como referência. Se nós deixarmos de lado a distinção entre ação cotidiana e contemplação estética e focarmos na arte como um processo de produção dos corpos em relações, poderemos enxergar o quanto os corpos e os artefatos são feitos por meio de técnicas semelhantes. Ao se desvanecer a distinção entre essas duas categorias, a eficácia estética das imagens se mostra inseparável de seus efeitos sociocosmológicos.

Enquanto na arte europeia a questão central é a produção de uma representação - seja imitação ou cópia - da imagem de um modelo original (uma figura material ou ideal), nas artes plásticas amazônicas o propósito é fazer corpos-artefatos dotados de potência de ação. Dialogando com os estudos sobre a arte, a artefatualidade e as ontologias transformacionais ameríndias, desenvolvidos por Van Velthem (2003), Viveiros de Castro (2004), Descola (2005) e Severi (2007), Lagrou sublinha que o que é imitado não é tanto a imagem de uma figura original, mas a sua capacidade de agir. Por exemplo, a aproximação feita por diversos povos ameríndios entre o tipiti e a cobra repousa sobre aquilo que o artefato-tipiti é capaz de fazer e aquilo que o corpo-cobra é capaz de fazer. A cobra se enrola na vítima e a tritura, assim como um tipiti aperta e espreme a massa de mandioca. Essa ênfase na agência dos corpos-artefatos abrange a produção do volume e a sua envoltura. Os grafismos que cobrem as superfícies, como na pintura corporal, na cerâmica, na cestaria e na tecelagem, também visam proporcionar capacidade de ação aos corpos-artefatos. Além disso, contribuem para desestabilizar a percepção de imagens fixas.

Partindo de sua análise dos desenhos huni-kuin, Lagrou (2011:768) argumenta que os grafismos que aderem aos corpos mobilizam o olho numa tensão incessante e apontam para o "entre-dois", para aquilo que conecta o movimento incessante entre fundo e figura, entre o que é visível e o que é invisível num dado momento, e vice-versa. Portanto, mais do que mostrar uma, ou várias imagens, os desenhos ensinam a ver a multiplicidade por trás de todo ato de percepção. A autora ressalta que na região, de maneira 
mais geral, as ontologias transformacionais permeiam as artes visuais e não permitem que as imagens se estanquem e parem de fluir (Lagrou 2013). Retomando o diálogo com a noção de quimera de Severi, ela propõe chamar de "quimera abstrata" o processo de projeção por parte do olho, e de inferência visual aquilo que é oculto a partir do que é dado a ver, sendo o olho "obrigado a completar motivos que foram apenas esboçados" (Severi \& Lagrou 2013:15). Nesse processo, grafismos aparentemente não figurativos podem existir simultaneamente com imagens figurativas engendradas num espaço mental a partir do preenchimento do que é implícito ou faltante.

Voltando ao nosso estudo sobre as obras de Roldán Pinedo e Enrique Casanto, surge a pergunta se a tensão visual apontada por Lagrou para a arte ameríndia também está operando nas suas técnicas visuais. O que acontece quando a figuração não é mais implícita, mas explícita, e o suporte material não é mais um corpo, e sim uma tela fixa? O que se pode atribuir à criação pessoal dos artistas ou à expressão de conhecimentos indígenas coletivos? Quanto provém da sua interação com a cidade? Como fica a questão da autoria? Estas perguntas, que só posso tentar responder no lugar dos dois protagonistas do meu estudo, têm uma abrangência maior para compreender o crescente envolvimento indígena nas artes contemporâneas no Peru e nos outros países amazônicos (Almeida \& Matos 2013; Soria Casaverde 2013; Moya 2013; Mattos \& Belaunde 2014).

No que diz respeito à multiplicidade das imagens por trás de todo ato de percepção, como mostrei acima, este é um elemento-chave da pintura de ambos os artistas. Mas nas suas telas a figuração não está mais implícita nos grafismos, ela não precisa ser completada, pois grafismos e figuração são vistos ao mesmo tempo. Mais precisamente, o que é tornado explícito nas telas é a relação entre grafismo e figura, na medida em que o fluxo das imagens é claramente dado a ver. Por exemplo, Pinedo pinta contornos figurativos dos corpos, mas usa esses contornos como molduras para preenchê-los de desenhos kene e de detalhes figurativos, mostrando a relação (implícita nas artes femininas) entre o kene e os desenhos das folhas e as peles dos animais. Casanto mostra o corpo ashaninka no momento da sua transformação, ao mesmo tempo ele próprio e seu duplo, humano e não humano e, também, plenamente humano enquanto duplo de si mesmo, singularizado pelas cores e pelos desenhos de suas roupas de tabaqueiro e de suas armas de guerreiro.

No que diz respeito à eficácia das novas pinturas, ambos os artistas produziram um novo tipo de corpo-artefato imerso nas relações políticas e comerciais com o público das cidades. O resultado é uma composição artefatual e gráfico-narrativa na qual o pessoal e o coletivo coexistem. Por 
um lado, a criação figurativa introduz o público e potenciais compradores para as cosmologias e as histórias dos povos dos artistas, buscando obter um reconhecimento e um retorno econômico vital para sua subsistência. Por outro, as cenas mostradas são imagens testemunhais das experiências visionárias pessoais do pintor, provenientes do uso ritual das plantas e do cumprimento dos resguardos. Além disso, suas pinturas articulam elementos diversos recolhidos pelos artistas nas suas trajetórias pessoais: seus processos de aquisição de conhecimentos no próprio coletivo cultural e com outros povos indígenas, bem como suas relações com professores escolares, intermediários culturais e clientes, nacionais e estrangeiros.

A nova pintura tem uma finalidade comercial, mas não se limita à integração no mercado e na sociedade nacional, pois não pretende promover a tolerância e o amortecimento das diferenças entre os mundos da capital e os mundos indígenas. Pelo contrário, o fazer criativo dos artistas afirma o movimento, a sobreposição, a multiplicidade e o embate político por meio das imagens. Desse modo, a pintura constitui-se como instrumento para subverter as hierarquias dominantes de poder e conduz ao surgimento de novas lideranças. Mas diferente das lideranças eleitas representantes das federações indígenas, os artistas indígenas exercem uma influência mais ampla e solta sobre setores indígenas e não indígenas do país. São formadores de opinião, cujo embate político se arma com as técnicas da ferocidade e da sedução das artes amazônicas. Eles ensinam a ver a transformabilidade das imagens e dos seres, mas também exigem a transformação do olhar das cidades para a floresta (Mattos \& Belaunde 2014:303).

\section{Conclusão: das plantas}

Para concluir, gostaria de voltar à relação entre donos e pintores assinalada no título deste artigo. Quando me refiro a Roldán Pinedo e a Enrique Casanto como pintores das plantas, não me refiro somente ao fato de que ambos retratam as plantas em suas telas, e nem que as usam como materiais de pintura. Reportar-me a ambos como "das plantas" busca também dar conta das múltiplas dimensões sociocosmológicas das plantas em suas imagens e seus efeitos sobre o público. Quando perguntei a Casanto se ele achava que suas pinturas tinham um potencial curativo, ele me disse: "só quem entende o que ele vê é curado". Ele expressou a dificuldade de produzir no seu público um olhar que não fosse um mero ato de apreciação estética visual, mas um ato de transformação da percepção e da ação. As pessoas "acham bonito", ele me disse, "mas não entendem". 
Nas minhas pinturas eu quero mostrar como agem as plantas, porque são as plantas que fazem com que as pessoas se transformem. Por isso eu pinto os guerreiros metade pessoa, metade outro ser. Eu falo com os políticos e até com congressistas aqui em Lima, mas eles não entendem que não se pode derrubar toda a floresta; não entendem que os animais têm dono, que os pássaros têm dono, que tudo tem seu dono. As pessoas das cidades veem meus quadros e acham bonito, mas elas não entendem. Por isso eu preciso explicar. Minha pintura é verídica; ela é o que o tabaco me diz quando o bebo.

O entendimento necessário para gerar uma transformação do olhar e da ação precisa de uma conexão com os donos das plantas e de todos os seres da floresta. A sua insistência no fato de que "tudo tem seu dono" evidencia uma preocupação característica das ontologias transformacionais ameríndias com noções de maestria, recentemente debatidas pela etnologia (Fausto 2008; Costa 2013). Como Barcelos Neto (2013) e Cesarino (2010) mostram, respectivamente, entre os Wauja e os Marubo, as figuras pintadas sobre papel pelos pensadores indígenas, para dar a ver aos antropólogos os seres de suas cosmologias, contêm informações-chave para compreender as concepções ameríndias da maestria e suas implicações visuais e musicais, pois as imagens também manifestam formas sonoras e cantos. Ao mesmo tempo, a meu ver, essas figuras sobre papel podem revelar mudanças nas artes visuais indígenas derivadas da introdução da figuração e do papel pela escola.

Nas pinturas de Pinedo e Casanto, a questão dos donos que percorre suas obras tem como ponto de partida a agência das plantas: a "mãe" da ayahuasca de Pinedo e a "avó" do tabaco de Casanto, ambas associadas à maestria sobre os piri piris. De forma interessante, são donos com alguns aspetos femininos que fornecem visões e conhecimentos sobre a diversidade dos outros donos sociocosmológicos e que "avisam" os pintores (de acordo com expressão de Pinedo) sobre como representá-los figurativamente na tela. Portanto, mais do que usar plantas para pintar, os dois artistas introduzem nas cidades, por meio de suas telas, regimes de visualidade das plantas. Por trás das imagens testemunhais da sua autoria, encontra-se a agência transformacional dos donos do mundo vegetal, e também os procedimentos rituais e os resguardos necessários para acessar a agência das plantas. Trata-se de dois artistas masculinos cujo trabalho criativo pessoal está regido, em particular, por suas relações com os aspectos femininos das plantas e de suas parceiras carnais e "não carnais", como destacou Casanto. Isto não significa que os donos das plantas sejam unicamente femininos ou que a feminilidade das plantas seja semelhante à feminilidade humana, mas essas ideias apontam para a importância central, ainda que pouco estudada pela etnologia, do gênero e da sexualidade nas ontologias ameríndias (Belaunde 2015b). 
Através da nova pintura, as plantas, enquanto sujeitos mestres inteligentes por excelência, enfrentam as cidades que lideram uma guerra de extermínio contra a floresta. Contra-atacando a objetivação e a destruição de seus habitantes, as plantas se infiltram nas cidades e respondem com uma estratégia do olhar. As imagens produzidas pelas novas técnicas figurativas desestabilizam a percepção dominante das cidades que privilegia a fixidez das formas e descarta outras em transformação, considerando-as híbridas, inconclusas ou imperfeitas, e perturbadoras de uma ordem visual na qual os corpos devem ter formas fixas para existirem e serem controláveis. Os efeitos de captura estética desenvolvidos pelos novos pintores "avisados" pelas plantas ensinam a ver a multiplicidade por trás de todo ato de percepção (Lagrou, 2011), mergulhando o olhar do público das cidades na transformabilidade e na inteligência dos seres para além de suas formas.

Recebido em 20 de abril de 2016

Aprovado em 26 de setembro de 2016

Luisa Elvira Belaunde é professora do Programa de Pós-Graduação em Antropologia Social, Museu Nacional, Universidade Federal do Rio de Janeiro, Rio de Janeiro/RJ, Brasil. E-mail: <luisaelvira@yahoo.com>

\section{Notas}

1 Os nomes e os sobrenomes completos dos artistas são Eniseas Enrique Casanto Shingari e Roldán Pinedo López, mas habitualmente eles são conhecidos pelo sobrenome paterno que, no Peru, é o sobrenome do meio (o último sobrenome é o da mãe). 


\section{Referências bibliográficas}

ALMEIDA, Maria Inês \& Beatriz MATOS (orgs.). 2013. Mira! Artes visuais contemporâneas dos povos indígenas. Belo Horizonte: Centro Cultural UFMG.

BARCELOS NETO, Aristóteles. 2013. "O trançado, a música e as serpentes da transformação no Alto Xingu". In: C. Severi \& E. Lagrou (orgs.), Quimeras em diálogo: grafismo e figuração na arte indígena. Rio de Janeiro: 7 Letras. pp. 181-198.

BELAUNDE, Luisa Elvira. 2008. "La narración de la memoria Aymenu (Uitoto) en la pintura de Rember Yahuarcani". Tellus, 8(14):247-255. 2009. Kene: arte, ciencia y tradición en diseño. Lima: Ministério de Cultura del Perú.

. 2010. "Las once lunas de Rember Yahuarcani". Mundo Amazónico, 1:333-348.

. 2011. "Visiones de espacios en la pintura del Sheripiare Asháninka Noé Silva Morales". Mundo Amazônico, 2:365-377.

. 2013a. "A pintura visionária xamânica da Amazônia peruana". In: M.I. Almeida \& B. Matos (orgs.), Mira! Artes visuais contemporâneas dos povos indígenas. Belo Horizonte: Centro Cultural UFMG. pp. 34-45.

. 2013b. "Movimento e profundidade no kene Shipibo-Konibo da Amazônia peruana". In: C. Severi \& E. Lagrou (orgs.), Quimeras em diálogo: grafismo e figuração na arte indígena. Rio de Janeiro: 7 Letras. pp. 199-222.

. 2015a. "Revivir a la gente: Herlinda Agustín, mujer onaya del pueblo shipibo-konibo". Mundo Amazónico, 6(2):131-143.

. 2015b. "O estudo da sexualidade na etnologia". Cadernos de Campo, 24:399-411.
BENDAYÁN, Christian \& VILLAR, Alfredo. 2013a. Pintura amazónica: El milagro verde. Lima: Forma e Imagen. 2013b. Usko ayar: la escuela de visiones. Lima: PetroPerú

BEYSEN, Peter. 2008. Kitarentse: pessoa, arte e estilo de vida ashaninka do oeste amazônico. Tese de Doutorado, Programa de Pós-Graduação em Sociologia e Antropologia, Instituto de Filosofia e Ciências Sociais, Universidade Federal do Rio de Janeiro. . 2013. "Kempiro: a arte gráfica dos traços fortes entre os Ashaninka do Oeste Amazônico". In: C. Severi \& E. Lagrou (orgs.), Quimeras em diálogo: grafismo e figuração na arte indígena. Rio de Janeiro: 7 Letras. pp. 223-246.

BURGA, Manuel. 2009. "La memoria como poder". La República (30 de abril de 2009). Disponível em: http://larepublica.pe/columnistas/ aproximaciones/la-memoria-como-poder-30-04-2009. Acesso em 23/10/2015.

BROWN, Michael \& FERNÁNDES, Eduardo. 1991. War of shadows: the struggle for utopia in the peruvian Amazon. Berkeley: University of California Press.

CASANTO, Enrique. 2002. Los guerreros ashaninka. Lima: Libros y Arte. 2005. Los piri piri: plantas medicinales. Lima: Seminario de Historia Rural de la Universidad Nacional Mayor de San Marcos.

. 2009. El poder libre Asháninca. Juan Santos Atahualpa y su hijo Josecito. Tradiciones asháninca. Lima: Universidad San Martín de Porres.

CASTILLOS TORRES, Daniel E. 2013. "Pintando en Shipibo". El arte de Cantagallo en Lima desde un contexto sociocultural. Los casos de Elena Valera, Pinedo Pinedo y los hermanos Guímer y Rusber García. MA. Dissertation, Pontificia Universidad Católica del Perú, Lima, Peru. 
CESARINO, Pedro. 2010. "Donos e duplos: relações de conhecimento, propriedade e autoria entre Marubo". Revista de Antropologia, 53(1):147197.

CHAVARRÍA, María. 2012. "De la oralidad a la literacidad, aproximaciones recientes en la Amazonía". In: J. P. Chaumeil; O. Espinoza \& M. Cornejo (orgs.), Por donde hay soplo. Estudios amazónicos en los países andinos. Lima: IFEA. pp. 433-464.

CHIRIF, Alberto. 2015. "Territorios indígenas en la coyuntura actual". In: A. Chiriff (ed.), Querido Perico. Pedro García Hierro, defensor de los derechos de los pueblos indígenas. Copenhague: IGWIA. pp. 310-325.

CLASTRES, Pierre. 2003 [1974]. A sociedade contra o Estado. São Paulo: Cosac \& Naify.

COLPRON, Anne Marie. 2005. “Monopólio masculino do xamanismo amazônico: o contraexemplo das mulheres xamãs shipibo-conibo". Mana. Estudos de Antropologia Social, 11(1):95-129.

COMISIÓN DE LA VERDAD Y DE LA RECONCILIACIÓN. 2003. "Los pueblos indígenas y el caso de los Ashaninka". Tomo V: Historias representativas de la violencia. Lima: Secretaría Nacional de la Juventud. pp. 241-177.

CORTÉS GARZÓN, Liliana. 2015. Amazónicos: un estudio de pintores amazónicos actuales. Ph.D. Dissertation, Universidad Autónoma de Barcelona, Espanha.

COSTA, Luiz. 2013. "Alimentação e comensalidade entre os Kanamari da Amazônia Ocidental". Mana. Estudos de Antropologia Social, 19(3):473-504.

DESCOLA (2005), Philippe. Par delà nature et culture. Paris: Gallimard.

ESPINOSA, Oscar. 1993. "Las rondas asháninka y la violencia política en la Selva Central". América Indígena, 53(4):79-102.
FAUSTO. Carlos. 2008. "Donos demais: maestria e domínio na Amazônia". Mana. Estudos de Antropologia Social, 14(2):329-366.

GEBHART-SAYER, Angelika. 1985. “The geometric designs of the Shipibo-Conibo in ritual context". Journal of Latin American Lore, 11:143-175.

GELL, Alfred. 1998. Art and agency: an anthropological theory. Oxford: Clarendon Press.

GOLDSTEIN, Ilana Seltzer. 2012. "Autoria, autenticidade e apropriação: reflexões a partir da pintura aborígine australiana. Revista Brasileira de Ciencias Sociais, 27(79):81-106.

HERBERT, Andrea. 2010. "Female Ayahuasca healers among the Shipibo-Konibo (UcayaliPeru) in the context of spiritual tourism". Núcleo de Estudos Interdisciplinares, NEIP. Disponível em: www.neip. info. Acesso em 25/06/2016.

ILLIUS, Bruno, 1992. "The concept of nihue among the Shipibo-Conibo of Eastern Peru". In: E. J. Langdon \& G. Baer (eds.), Portals of power. shamanism in South America. Albuquerque: University of New Mexico Press. pp. 63-77.

. 1994. "La gran boa: arte y cosmología de los shipibo-conibo". Amazonía Peruana, 24:185-212.

LAGROU, Els. 2007. A fluidez da forma: arte e agência em uma sociedade amazônica (Kaxinawa, Acre). Rio de Janeiro: Top Books Editora.

. 2011. "Existiria uma arte das sociedades contra o Estado?". Revista de Antropologia, 54(2):745-780.

2013. "Podem os grafismos ameríndios ser considerados quimeras abstratas? Uma reflexão sobre uma arte perspectivista". In: C. Severi \& E. Lagrou (orgs.), Quimeras em diálogo: grafismo e figuração na arte indígena. Rio de Janeiro: 7 Letras. pp. 111-138.

LANDOLT, Gretna. 2000. El ojo verde. Cosmovisiones amazónicas. Lima: Fundación Telefónica. 
2005. El Ojo que cuenta: mitos y costumbres de la Amazonía indígena ilustrados por su gente. Lima: ICAM.

LECLERC, Frédérique. 2003. "Función de los diseños kené en la población shipibo-conibo: una visión holística del mundo". In: C. Alés; J. Chappino \& M. Harris (eds.), Image, performance and representation in American shamanic societies. St. Andrews: University of Saint Andrews Press. pp. 117-124.

LUNA, Luis Eduardo \& AMARINGO, Pablo. 1991. Ayahuasca visions: the religious iconography of a Peruvian shaman. Berkeley: North Atlantic Books.

MACERA, Pablo; MACERA, Javier \& SORIA, Belén. 2010. Cuentos pintados del Perú: awajún, asháninka, shipibo-konibo. Lima: Fondo Editorial del Congreso de la República del Perú.

MATTOS, Beatriz \& BELAUNDE, Luisa Elvira. 2014. "Arte e transformación: experiencias e imágenes de los artistas de la exposición iMira!". Mundo Amazónico, 5:297-308.

MOYA, Ruth. 2013. "O mundo amazônico e o mundo andino em dois pintores equatorianos na Exposição MIRA!". In: M. I. Almeida \& B. Matos (orgs.), Mira! Artes visuais contemporâneas dos povos indígenass. Belo Horizonte: Centro Cultural UFMG. pp. 51-62.

MYERS, Fred. 1995. "Representing culture: the production of discourse(s) for Australian Aboriginal acrylic painting". In: G. Marcus \& F. Myers (orgs.), The traffic in culture: refiguring art and anthropology. Berkeley: University of California Press. pp. 55-95.

ROE, Peter. 1979. "Marginal men: male artists among the Shipibo-Conibo indians of Peru". Anthropologica, 21(2):189-221.

SANTOS, Fernando \& BARCLAY, Federica. 1995. Guía etnográfica de la Alta Amazonía. v. 5. Arequipa: IFEA.
SEVERI, Carlos. 2007. Le principe de la chimère. Une anthropologie de la mémoire. Paris: Éditions Rue d'Ulm.

SEVERI, Carlos \& LAGROU, Els. 2013. "Introdução". In: __. (orgs.), Quimeras em diálogo: grafismo e figuração na arte indígena. Rio de Janeiro: 7 Letras. pp. 11-24.

SORIA CASAVERDE, María Belén. 2013. "Uma mira na MIRA! O caráter integrador e a natureza múltipla da arte indígena contemporânea". In: M. I. Almeida \& B. Matos (orgs.), Mira! Artes visuais contemporâneas dos povos indígenas. Belo Horizonte: Centro Cultural UFMG. pp. 9-17.

TOURNON, Jacques. 2006. Los rao e sus espíritus. Etnobotánica del Ucayali. Pucallpa: Gobierno regional del Ucayali.

TRAPNELL, Lucy. 2015. "Currículos y paradigmas civilizatórios: apuntes para un debate". In: A. Chiriff (ed.), Querido Perico. Pedro García Hierro, defensor de los derechos de los pueblos indígenas. Copenhague: IGWIA. pp. 275-289.

VALENZUELA, Pilar \& VALERA, Agustina. 2005. Koshi shinanya ainbo. El testimonio de una mujer shipiba. Lima: Universidad Nacional Mayor de San Marcos.

VAN VELTHEM, Lucia. 2003. O belo é a fera: a estética da produção e da predação entre os Wayana. Lisboa: Editora Assírio \& Alvin.

VIVEIROS DE CASTRO, Eduardo. 2004. "Exchanging perspectives: the transformation of objects into subjects in Amerindian ontologies". Common Knowledge, 10(3):463-484. 
DONOS E PINTORES: PLANTAS

E FIGURAÇÃO NA AMAZÔNIA PERUANA

\section{Resumo}

O artigo aborda um movimento inovador da pintura liderado por artistas indígenas, nascidos e escolarizados na Amazônia, que migraram para Lima, a capital do Peru, onde se destacaram por suas obras. O estudo centra-se em dois pintores eminentes deste cenário, Roldán Pinedo e Enrique Casanto, analisando as conexões entre suas pinturas e os entornos sociocosmológicos nos quais se inserem. O texto ressalta o alcance político de suas propostas plásticas e argumenta que os artistas amazônicos introduzem novos modos de conceber as imagens e as relações com as plantas que desafiam as percepções da floresta e dos povos indígenas impostas pela cidade.

Palavras-chave: Arte indígena, Amazônia peruana, Roldán Pinedo, Enrique Casanto, Pintura amazônica.

\section{DUEÑOS Y PINTORES: PLANTAS Y \\ FIGURACIÓN EN LA AMAZONIA PERUANA}

\section{Resumo}

El artículo aborda un movimiento de pintura innovador liderado por artistas indígenas, nacidos y escolarizados en la Amazonia, que migraron a Lima, la capital del Perú, donde lograron destacarse por sus obras. El estudio enfoca a dos eminentes pintores de este escenario, Roldán Pinedo y Enrique Casanto, analizando las conexiones entre sus pinturas y los entornos sociocosmológicos en que se insieren. El texto resalta el alcance político de sus propuestas plásticas y argumenta que los artistas amazónicos introducen nuevos modos de concebir las imágenes y las relaciones con las plantas que desafían las percepciones del bosque y de los pueblos indígenas impuestas por la ciudad.

Palabras llaves: Arte indígena, Amazonia peruana, Roldán Pinedo, Enrique Casanto, Pintura amazónica 
OWNERS AND PAINTERS: PLANTS AND FIGURATION IN THE PERUVIAN AMAZON

\begin{abstract}
The paper examines a new painting movement led by indigenous artists born and schooled in the Amazon who migrated to Lima, the Capital of Peru, where their works of art obtained outstanding recognition. The study focuses upon two eminent painters of
\end{abstract}

this scene, Roldán Pinedo and Enrique Casanto, analysing the connections between their paintings and their socio-cosmological surroundings. The text highlights the political scope of their visual proposals and argues that Amazonian artists introduce new modes of conceiving images and their relationships with plants, defying the perception of the forest and indigenous peoples imposed by the city.

Key words: Indigenous art, Peruvian Amazon, Roldán Pinedo, Enrique Casanto, Amazonian painting. 